UDK: 811.163.41'37; 811.111'37; 811.163.41:811.111

\title{
- SEMANTIČKA ORGANIZACIJA DELOVA KUĆE PREMA SRPSKIM I AMERIČKIM ISPITANICIMA
}

\author{
BRANISLAVA DILPARIĆ ${ }^{1}$ \\ Univerzitet u Prištini, Filozofski fakultet, \\ Katedra za engleski jezik i književnost, \\ Kosovska Mitrovica, Srbija
}

U radu² se porede rezultati ankete sprovedene među dve grupe ispitanika, izvornih govornika srpskog i izvornih govornika (američke varijante) engleskog jezika, sa ciljem (1) da se stekne uvid u semantičku organizaciju članova kategorije delovi kuć i (2) da se ustanovi koje se to vrste entiteta svrstavaju u ovu kategoriju. Za pokazatelje unutrašnje strukture kategorije korišćene su dve mere: učestalost i redosled navođenja naziva za njene članove. Rezultati pokazuju da ispitanici, generalno uzevši, među delove kuće svrstavaju ne samo (segmentalne i sistemske) delove samog građevinskog objekta, već i elemente pokućstva koje on, shodno svojoj funkciji, tipično sadrži, kao i različite površine/objekte koji se na nekom imanju nalaze izvan njega. Ipak, kao najbolje predstavnike kategorije i srpski i američki ispitanici izdvajaju segmentalne delove građevine, kako strukturne, tako i prostorne.

Ključne reči: teorija prototipa, kategorija, unutrašnja struktura, odnos deocelina (meronimija), DELovi KUĆE.

\section{UVOD}

Prema teoriji prototipa, svaka prirodna kategorija formira se oko svog konceptualnog jezgra ili zamišljenog 'ideala' i ima složenu gradijentnu strukturu koju čine njeni bolji i lošiji predstavnici, odn. entiteti koji u manjoj ili većoj meri odstupaju od njenog prototipa (v. Rosch 1975). Tako formirana, kategorija može pripadati i većim konceptualnim skupinama kategorija kao što su hijerarhijski ustrojene taksonomije i meronomije (partonomije) i koherentna područja konceptualizacije poput okvira (frejmova) i domena (Radden \& Dirven 2007: 8). Konceptualno grupisanje kategorija u

1 Kontakt podaci (Email): danya@open.telekom.rs

2 Rad je rezultat istraživanja koje se sprovodi u okviru projekta br. 178019 Ministarstva prosvete i nauke Republike Srbije. 
meronomijezasniva se na odnosu deo-celina kakav je, recimo, odnos između kategorija MOTOR, TOČAK, KAROSERIJA i dr. i kategorije AUTO. Na nižim nivoima hijerarhije, deo neke celine može i sam predstavljati celinu koja se sastoji od svojih delova, npr. TočAK od RADILIA, KLIP, CILINDAR i dr., CILINDAR Od SVEÉIIA, OSOVINA, VENTIL, itd. (Radden \& Dirven 2007: 9). ${ }^{3}$

Iako odnos između delova i celina ima dugu tradiciju proučavanja, a od dvadesetog veka se nalazi i u domenu više stručnih disciplina (logika/filozofija, psihologija, lingvistika, vizuelna percepcija, veštačka inteligencija i dr.), u nauci još uvek ne postoji jedna opšteprihvaćena teorija koja bi obuhvatila i objasnila sve dosta kompleksne pojave koje se za njega vezuju. Štaviše, među teoretičarima još uvek ne postoji opšta saglasnost ni kada je određenje samih pojmova 'deo' i 'celina' u pitanju, ni kada je u pitanju utvrđivanje statusa i definisanje odnosa deo-celina (v. Gerstl \& Pribbenow 1995). $\mathrm{Na}$ području lingvistike, gde je ovaj odnos češće imenovan terminom meronimija, ${ }^{4}$ najstrože kriterijume za njegovo određenje postavio je Dejvid A. Kruz. Smatrajući da kategoriji PART (DEo) odgovara tek jedno značenje iz veoma širokog semantičkog opsega reči part, on predlaže da se za izolovanje tog značenja, odn. utvrđivanje odnosa meronimije, koristi dvopartitni dijagnostički test: $A(n) X$ is a part of $a(n) Y$ i $A(n) Y$ has Xs/ $a(n) X$, pri čemu se i $X$ kao meronim (tj. naziv za deo) i $Y$ kao holonim (tj. naziv za celinu) moraju tumačiti isključivo u generičkom smislu (Cruse 1995: 160; Croft \& Cruse 2004: 153). Ukoliko nazivi za deo neke celine i tu celinu 'prođu' oba dela pomenutog testa, onda je reč o „pravoj meronimiji", tj. „pravom” delu posmatrane celine, a ukoliko neki od rečeničnih okvira ispitivani nazivi ne zadovolje, onda među njima postoji odnos koji je tek sličan meronimiji, ali nije i sam meronimija (v. Cruse 1995: 160-161; 172-177).

3 Kao u svakoj (granajućoj) hijerarhijskoj strukturi, i u meronimijama se članovi, odn. delovi neke celine sa istog nivoa hijerarhije prikazuju tako što se postavljaju jedan pored drugog, a oni sa različitih nivoa jedan ispod drugog (v. Cruse 1995: 157; Radden \& Dirven 2007: 9). Međutim, u konceptualnom smislu ti delovi su integrisani u celinu koju čine i u kojoj svaki od njih ima svoje mesto i svoju funkciju. Takvu sposobnost razumevanja koherentne "prirode” stvari omogućavaju nam konceptualni okviri (frejmovi), tj. koherentni „paketi znanja” koji natkriljuju kategorije i koji se aktiviraju svaki put kada mislimo ili komuniciramo o stvarima. Na primer, kada čujemo rečenicu Možeš li da upališ auto? [u stvari, motor auta] ili Možeš li da usisaš auto? [u stvari, unutrašnjost auta], zahvaljujući zajedničkom poznavanju frejma 'auto' mi odmah „znamo" da se misli na neki deo auta $\mathrm{i}$, štaviše, na koji to deo bez obzira na to što je u oba slučaja u stvari imenovan samo auto kao celina. I dok frejmovi predstavljaju strukture specifičnog znanja koje okružuju kategorije, konceptualni domeni su šira područja konceptualizacije kojima neka kategorija ili okvir pripada u datoj situaciji, npr. nož pripada domenu 'obedovanje' kada se, recimo, za vreme doručka koristi za sečenje hleba ili dr., a u domenu 'borba' kada se koristi kao oružje (Radden \& Dirven 2007: 9-11).

4 U leksikologiji se meronimiji tradicionalno poklanja mnogo manje pažnje nego drugim paradigmatskim odnosima (sinonimiji, antonimiji, hiponimiji i dr.), jer, kako smatra Lin Marfi, meronimija nije čisto lingvistički odnos, tj. ona nije ni čisto leksički odnos (odnos između reči), ni čisto smisaoni odnos, tj. odnos između značenja reči (npr. iako je rep deo psa, 'rep' ne mora obavezno biti i deo značenja reči pas, niti 'pas' deo značenja reči rep), već pre odnos između denotata koje te reči označavaju (2003: 9; 2006: 13). Ipak, zahvaljujući skorašnjim izmenama u pristupima značenju koji su više usmereni na interfejs između jezika i uma i brišu razliku između rečničke i enciklopedijske informacije (čiji bi deo bila i meronimija), ovaj odnos dobija na većoj važnosti, naročito na području primenjene lingvistike. Na meronimiju se danas gleda kao na jedan od centralnih odnosa (pored hiponimije) koji služi za sastavljanje rečničkih definicija. Jer, kako se značenje u novim (kognitivističkim) pristupima ne tumači pomoću klasičnog (aristotelovskog) skupa nužnih i dovoljnih obeležja već je zasnovano na pojmu prototipa ili idealnih primera neke kategorije, meronimijski odnos poput pas > rep može biti uključen u predstavljanje značenja reči pas pošto se time nikako ne implicira da svako stvorenje koje nazivamo tim imenom mora obavezno i imati rep. Trenutno interesovanje za meronimiju podstaknuto je i aktuelnim projektima obrade prirodnih jezika i izradi leksičkih baza podataka (npr. WordNet, EuroNet, BalkaNet) u kojima se kao neizostavna komponenta predstavljaju i različiti tipovi meronimije (Murphy 2006: 13, 15). 
Vinston, Šafin i Herman, s druge strane, definisanje meronimije pomoću konstrukcije part of (sa celokupnim semantičkim opsegom reči part) ne samo da ne ograničavaju dodatnim dijagnostičkim okvirom kao što to čini Kruz pomenutom havekonstrukcijom, već ga i proširuju uvođenjem rečeničnog okvira sa izvedenicom partly - $X$ is partly $Y$, npr. Bicycles are partly aluminium (1987: 418). Time oni pod meronimiju svrstavaju većinu odnosa koje Kruz vidi tek kao kvazimeronimiju ili nemeronimiju, smatrajući ih potpuno ravnopravnim članovima jedne meronimijske porodice: (1) component - integral object (pedal - bike); (2) member - collection (ship - fleet); (3) portion - mass (slice - pie); (4) stuff - object (steel - car); (5) feature - activity (paying shopping); (6) place - area (Everglades - Florida) (v. Winston, Chaffin \& Herrmann 1987: 420-426).

Polazeći od osnovnih postulata teorije prototipa - gradijentna struktura kategorija i fleksibilnost njihovih granica, možda bi se izneta gledišta kategorije PART (i meronimije), iako nesumnjivo različita, ipak mogla videti i kao ne toliko suprotstavljena koliko se u prvi mah čine. Jer, široko poimanje kategorije PART Vinstona i njegovih saradnika moglo bi u stvari da ukazuje na sve ono što ovoj kategoriji može pripadati, pa makar obitavalo i samo na njenim perifernim delovima, dok bi Kruzovo uže definisanje kategorije moglo ilustrovati samo njeno jezgro, odn. izdvojiti njene najbolje predstavnike.

\section{KATEGORIJA DELOVI KUĆE: ČLANOVI I NJIHOVA ORGANIZACIJA}

Meronimija je, kao što je rečeno, smisaoni (sadržinski) odnos koji, sledeći trijadnu koncepciju znaka Ogdena i Ričardsa, pripada sferi denotacije i na kom se zasniva jedan od načina hijerarhijskog organizovanja leksikona (Šipka 1998: 43; Cruse 1995: 157). Stoga, dobijene leksičke hijerarhije, tzv. meronimije, predstavljaju u stvari lingvistički odraz ekstralingvističke hijerarhije bazirane na odnosu deo-celina između kojih se, uprkos čestim poklapanjima, javljaju i izvesne razlike, npr. u meronimiji ljudskog tela, tj. hijerarhiji naziva za delove tela, prikazuje se samo jedan čvor za ruku i jedan za nogu, dok u ekstralingvističkoj hijerarhiji i za ruku i za nogu postoje po dva čvora (Cruse 1995: 160). Takođe je rečeno da se za signalizatora meronimije tipično uzima reč deo, ali i da se teorijska gledišta o tome koliki udeo iz vrlo širokog semantičkog opsega ove reči zaista i odgovara kategoriji dEo uglavnom podosta razlikuju.

Imajući ovo u vidu, prilikom odabira građe za jedno šire ispitivanje leksičkosemantičke grupe kuća i njeni delovi u srpskom i engleskom jeziku, autor ovog rada suočio se sa nizom pitanja i dilema: (a) Da li 'kuću kao celinu' treba shvatiti samo kao vrstu fizičkog (konkretnog) objekta ili, preciznije, tip građevinske strukture i pod delovima kuće smatrati jedino (segmentalne i sistemske) delove samog građevinskog objekta, i eventualno delove tih delova5? (b) Postoji li u tom slučaju ikakvo opravdanje da se u građu uključe i nazivi za materijale od kojih se kuća, odn. neki njen deo pravi uprkos tome što pomenuti nazivi uglavnom predstavljaju nebrojive imenice a sam holonim brojivu imenicu?; (c) Ako je tako, do kojih bi granica to 'razlaganje' uopšte dosezalo, da li npr. samo do maltera ili betona ili, možda i dalje, do cementa, peska,

50 lancima entiteta zasnovanim na odnosu deo-celina v. u Croft \& Cruse (2004: 154-156). 
kreča, vode kao njihovih sastojaka? (Ipak, Voda je deo kuće ili Kuća je delom voda zvuče u najmanju ruku čudno.); (d) Da li 'kuću kao celinu' posmatrati i kao sadržatelja6', odn. da li se po principu prostorne uključenosti pod delovima kuće mogu podrazumevati i elementi pokućstva, koji, dakle, ne predstavljaju komponente same građevinske strukture već se samo nalaze unutar nje?; (e) Da li 'kuća kao celina' možda izlazi i van ovog fizičkog okvira i po principu prostorne (i funkcionalne) bliskosti zahvata i područje/prostor oko njega, verovatno ne dalje od granica jednog imanja?; (f) Da li bi se u tom slučaju među delove kuće zaista mogli uvrstiti baš svi entiteti koji se nalaze na nekom imanju?; (g) Koji bi se od njih onda našli u samom jezgru ove kategorije a koji na njenoj periferiji? itd.

Kako odgovore na ova i slična pitanja nisu mogle da pruženileksikografske definicije naziva za moguće delove kuće preuzete iz većeg broja deskriptivnih rečnika oba jezika, odluka o uključivanju, odn. izostavljanju pojedinih leksema iz građe bila bi prepuštena jedino istraživaču i njegovom (u većini slučajeva) tek intuitivnom gledištu. Pomoć je, stoga, potražena od većeg broja ispitanika, izvornih govornika srpskog i izvornih govornika (američke varijante) engleskog jezika, u anketi održanoj u Kosovskoj Mitrovici, Srbija, i Atlanti, Džordžija, SAD. Anketa je imala dva cilja: (1) steći uvid u semantičku organizaciju članova kategorije delovi kućE i (2) ustanoviti koje to vrste entiteta ispitanici svrstavaju u ovu kategoriju. Za indikatore unutrašnje strukture kategorije odabrane su dve mere: učestalost i redosled navođenja naziva za njene članove, za koje je u jednom od ranijih eksperimenata pokazano da se nalaze u značajnoj korelaciji sa stepenom tipičnosti članova neke kategorije (v. Mervis, Catlin \& Rosch 1976). U anketi je navedeno ukupno 497 naziva, uključujući sinonime, od kojih je srpskih bilo 270 a engleskih 227. Semantičke organizacije članova posmatrane kategorije prikazane su u vidu rang-lista koje su date u Дилпарић (2011) (prema srpskim ispitanicima) i Dilparić (2012) (prema američkim ispitanicima).

$\mathrm{U}$ ovom radu daje se pregled sličnosti i razlika između pripadnika dve kulture $u$ poimanju kuće kao celine, klasifikovanju entiteta u kategoriju njenih delova i njihovoj organizaciji unutar kategorije.

(1) Imajući u vidu sve nazive navedene u anketi, 'kuću kao celinu' obe grupe ispitanika, generalno uzevši, tumače na sva tri gore pomenuta načina: (a) kao vrstu fizičkog objekta, odn. tip građevine sastavljene od svojih karakterističnih segmentalnih i sistemskih delova7; (b) kao sadržatelja, odn. unutrašnji prostor definisan (i segmentovan) pomenutim fizičkim okvirom koji, shodno funkciji koju ima, tipično sadrži najrazličitije elemente pokućstva; (c) kao šire područje/prostor koji osim kuće kao građevinskog objekta zahvata i okućnicu, sa različitim entitetima koji se na njoj mogu naći.

(2) Ipak, na obe liste naziva za delove kuće nazivi za one entitete koji se uvek nalaze izvan glavne zgrade na nekom imanju javljaju se u dosta malom broju. Ovo uključuje dvorište, travnjak, baštu, ogradu, staze, kao i poneke vrste pomoćnih, uglavnom smeštajnih objekata poput šupe, štale, ambara i sl. Njihovi rangovi i na srpskoj i na američkoj listi tipičnosti pokazuju da se ovi entiteti, iako uključeni u kategoriju, ipak ne vide i kao njeni

6 Od engl. container (v. Lakoff \& Johnson 2003: 29).

70 razlikama između ova dva opšta tipa delova v. u Cruse (1995: 169) i Croft \& Cruse (2004: 154). 
dobri predstavnici. Najbolje kotirani među njima su OGRADA (38/36) ${ }^{8}$ i DVoRIŠTE (46/47), sjedne, i yaRD (30/26), s druge strane, a daleko iza njih, zaključno sa 80. mestom, našli su se i sledeći najbolje rangirani entiteti: BAŠTA (76/68), LAWN (58/57), GARDEN (71/70) i DRIVEWAY (76/79).

(3) Posebno je posmatrana grupa entiteta kao što su garaža, radionica, kotlarnica, zimska bašta, bazen, fontanai sl., koji se, shodno mogućim varijacijama u arhitektonskim rešenjima, na jednom imanju mogu naći ili u sklopu glavne zgrade, ili izvan nje. Većina tih entiteta, dakle, može predstavljati ili segmentalne delove same kuće ili pak zasebne, pomoćne objekte, odn. delove takvih objekata. Iako su, generalno uzevši, rangovi ovih entiteta na listama tipičnosti podosta razuđeni, njihova veća koncentracija uočava se pri dnu obe liste, što znači da većinu njih ispitanici takođe vide tek kao periferne članove kategorije. Kao najbolji predstavnik dela kuće u odnosu na sve druge entitete iz ovde posmatrane grupe u oba slučaja izdvojio se isti objekat/prostorija - GARAžA / GARAGE. Štaviše, na američkoj listi on je pozicioniran već na 5/8. mestu, dok na srpskoj listi on zauzima tek 35/33. mesto. Od ostalih takvih entiteta ističu se još i sunRoom / FLoRIDA ROOM (31/27) i LAUNDRY ROom (36/35), dok su daleko od njih pozicionirani sledeći najbolje rangirani: POoL (85/77) i STORAGE (ROOM) (88/86). Na srpskoj listi, posle GARAZ̈E, entiteta iz ove grupe nema sve do 121/120. mesta na kom se nalazi BAZEN.

(4) Pojedini američki ispitanici među delove kuće svrstavaju i manji broj entiteta koji ne predstavljaju građevinske tvorevine ili njihove delove poput navedenih pod tačkom (3), ali se kao i oni na nekom posedu mogu naći ili (samo) izvan kuće ili unutar nje. To su pojedine vrste prevoznih sredstava (CAR, BICYCLE), životinja, uglavnom kućnih Ijubimaca (PETS, DOG, CATS, TURTLE, SQUIRRELS) i biljaka (TREES, PLANTS, GRASS). Vrlo niske statističke vrednosti oba posmatrana parametra $\left(\Sigma_{1} i \Sigma_{2}\right)$, međutim, ukazuju na sasvim perifernu pozicioniranost svih navedenih entiteta unutar kategorije (od 72. mesta pa nadalje), što se takođe odnosi i na (sobNo) cvećE kao jedinog člana iz posmatrane grupe koji se našao na srpskoj listi.

(5) Najrazličitije elemente pokućstva, tj. kućni nameštaj i opremu koja se koristi u domaćinstvu, obe grupe ispitanika nesumnjivo vide kao delove kuće. Njihove nazive, štaviše, američki ispitanici navode i u najvećem broju. Njihov udeo među svim popisanim nazivima iznosi 54,62\% na američkoj i 37,92\% na srpskoj listi. Iako se nijedan elemenat pokućstva ne smatra i najtipičnijim delom kuće, nekolicina njih je ipak našla svoje mesto u blizini samog središta kategorije. Ovo se pre svega odnosi na američku listu na kojoj su se među šesnaest prvoplasiranih članova našla čak četiri takva entiteta: closets (10/10), (Kitchen/Dining) TABLE (12/13), television (14/15) i chairs (15/16), a među prvih dvadeset dva još i Beds (20/20), SOFA/COUCH (21/21) i cARPETs (22/22). Sličnih entiteta na srpskoj listi nema sve do 18/18. mesta na kom je pozicioniran KREVEt, a među prva dvadeset dva člana našli su se još samo sтo (19/19) i stolice (20/22).

(5a) Među navedenim elementima pokućstva, kao što se vidi, u oba slučaja dominiraju komadi (sobnog, kuhinjskog, kupatilskog) nameštaja. Od ostalih članova te

8 I srpska i američka lista delova kuće sortiranih po opadajućem stepenu tipičnosti sastoji se u stvari od po dve liste, jedne sastavljene prema skoru za učestalost $\left(\Sigma_{1}\right)$ i druge prema skoru za redosled $\left(\Sigma_{2}\right)$ navođenja njihovih naziva. Između tih lista u oba slučaja javlja se značajna podudarnost, što je potvrđeno i statistički. U nastavku rada pozicioniranost nekog entiteta u jednoj i drugoj listi navodiće se, bez posebnog isticanja, prvo prema $\Sigma_{1}$ a potom prema $\Sigma_{2}$ npr. oGRADA (38/36) znači da je ovaj entitet pozicioniran na 38. mestu u listi sastavljenoj prema $\Sigma_{1}$ i na 36. mestu u listi sastavljenoj prema $\Sigma_{2}$. 
kategorije bolju poziciju među delovima kuće zauzeli su još (KITCHeN) SINK (29/24) i caBINETS (34/33), te ORMAR (33/34) i SUDOPERA (40/42).

(5b) Osim na američkoj, Televizor se i na srpskoj listi pokazao kao najbolje kotiran uređaj koji se koristi u domaćinstvu (23/25), a slede ga ŠPORET (34/38), FRIŽIDER (41/46) i kомpJuteR (50/55) kao nešto bolje rangirani članovi ove kategorije. Isti uređaji se po identičnom redosledu ređaju i na američkoj listi nakon television, iako sa dosta boljim pozicijama nego na srpskoj: stove (25/29), REFrigerator (28/37) i COMPUTER (38/38).

(5c) Denotacioni opseg i naziva šporet i naziva stove, međutim, obuhvata i one vrste šporeta koje osim za pripremanje hrane služe i za zagrevanje prostorija, te bi se takva klasa entiteta, osim u kategoriju uređaja, mogla klasifikovati i među grejna tela. Posmatrano na taj način, ŠPORET (34/38) bi na srpskoj listi predstavljao najbolje rangirano grejno telo daleko ispred kAmina (55/54) i RADIjatoRA (68/73), dok bi na američkoj listi FirePLACE (24/23) zamalo pretekao STove (25/29), a na daleko lošijim pozicijama u odnosu na njih našli bi se i sledeći najbolje kotirani fuRNACE (48/47) i HeATERS (53/52).

(5d) Sanitarije, kojima se ovde pridružuje i tuš(-kabina), ređaju se po donekle sličnom redosledu na obe liste, s tim što srpska sadrži nešto veći broj takvih entiteta, a oni koji se nalaze i na američkoj listi uglavnom imaju znatno bolju poziciju nego na srpskoj: KADA (37/40), LAVABo/umivaoniK (54/57), wC Š0Lja (56/58), tuš-KABina (73/74), ĐAKUZI (KADA) (95/93), BIDE (103/118) i tuš (144/151); (BATH)tuB (23/25), SHOWER (26/31), (BATH)SInK (33/30), toIlet (35/34) i JaCuZzi (219/219).

(5e) Među podnim prostirkama, čiji su nazivi na obema listama navedeni u izrazito malom broju, u oba slučaja dominira теPIH (25/28) / CARPETs (22/22), kojeg na srpskoj listi sledi još samo daleko pozicionirani otiRač (174/132), a na američkoj RuGs (50/51) i, takođe, DOORMAT (175/176).

(5f) Nazivi za rasvetna tela, uključujući i hiperonime i hiponime, takođe se u malom broju navode na obe liste, a njihov redosled po rangu jeste sledeći: LUSTER (29/31), LAMPA (69/72), OSVETLENJE (234/254); LIGHS (41/42), LAMPS (107/106), CHANDELIERS (205/205).

(5g) Različite vrste posuda, pribor za jelo, delovi posteljine i drugi (uglavnom) tekstilni elementi pokućstva kao što su zavese, stoljnjaci, salvete, peškiri, krpe, te ukrasni predmeti kao što su slike, svećnjaci, vaze takođe predstavljaju marginalne članove kategorije. Među njima se ističu jedino zavese zauzevši 36/37. poziciju, a do 80. mesta na srpskoj listi javljaju se još samo sLike (58/60) i, eventualno, (soBno) cvEćE (72/76), ukoliko bi se i ono posmatralo kao vrsta kućnog ukrasa. Među prvih osamdeset prvoplasiranih članova na američkoj listi pak uglavnom se javljaju posude: Dishes (55/55), POTs (61/64) i PANs (62/65), i takođe PICTURES (75/76).

(5h) Za razliku od nekolicine američkih ispitanika, nijedan srpski ispitanik među delove kuće nije kategorisao komade odeće ili obuće uprkos tome što se i oni, kao i svi navedeni u tački (5), mogu nalaziti $u$ kući. Na američkoj listi oni se većinom imenuju hiperonimima clothes, clothing, shoes, a njihovi rangovi takođe ukazuju na dalju pozicioniranost unutar kategorije: cLothes / CLOTHING (52/50), SHOES (72/71).

(5i) Srpski ispitanici kao delove kuće ne vide ni razne entitete iz kategorije alata ili oruđa. Na američkoj listi javljaju se tek dva takva člana i to na vrlo lošim pozicijama: BILLHOок (134/129) i (KNIFE) SHARPENER (151/149).

(5j) Takođe u manjem broju i uglavnom na lošim pozicijama na obe liste javljaju se i strukturne komponente delova pokućstva: oven (25/29) < stove, FAUCETS $(63 / 74)$ < (KITHEN) 
BATH) SINK / (BATH)TUB / SHOWER, HEARTH (206/206) < FIREPLACE, BULBS (209/209) < LIGHTS / CHANDELIERS / LAMPS, SHOWER HEAD (217/217) < SHOWER; SIJALICA (59/59) < LUSTER / LAMPA, ČESMA/SLAVINA (63/62) < SUDOPERA / LAVABO / KADA / TUŠ, ABAŽUR (195/215) < LAMPA, RAM ZA SLIKE $(242 / 206)$ < SLIKE, ČUNAK (256/193) < ŠPORET NA DRVA, itd. ${ }^{9}$

(6) Udeo naziva za najrazličitije delove kuće posmatrane sada isključivo kao građevinske strukture među svim popisanim nazivima u anketi pokazao se daleko većim na srpskoj (53,53\%) nego na američkoj listi $(31,72 \%$, odn. $37 \%$ računajući i entitete navedene pod tačkom (3)). Ovo navodi na zaključak da je naziv kategorije kao zadati stimulus srpske ispitanike prvenstveno asocirao na građevinsku strukturu dok su američki ispitanici u tom pogledu bili pre svega usredsređeni na njen sadržaj (v. udeo naziva za pokućstvo na američkoj listi u tački (5)). Navedeni procenti uključuju nazive za segmentalne (prostorne i strukturne) delove kuće, delove strukturnih delova kuće, sistemske delove kuće i njihove komponente, kao i materijale od kojih se ova struktura, odn. neki njen deo pravi, ukrašava ili fiksira. ${ }^{10}$

(6a) Ispitanici, dakle, materijale ipak svrstavaju među delove kuće. Međutim, dok su američki ispitanici njihove nazive na svojim listama naveli u nešto manjem broju (STONE, WOOD, BRICK, SHINGLES, TILE ${ }^{1}$ (= crep), TILE$^{2}$ (= (keramičke) pločice), GROUT, FLOORING, SIDING, DRY WALL, SLAB, TRIM, MOLDING, NAILS, STAPLES, SCREWS, itd.), na srpskoj listi broj takvih naziva je pozamašan. Ovo podrazumeva ne samo nazive za izvorne gradivne materijale poput drveta, kamena, peska, zemlje, metala, vode nego i nazive za najrazličitije forme građevinskih materijala koji su od prethodnih dobijeni ili samo njihovom obradom ili pak mešanjem sa nekim drugim sastojcima, npr. kreč, cement, malter, beton, armatura, staklo, staklena vuna, stiropor, daske, grede, letve, parket, keramičke pločice, crep, cigla, blokovi, ćerpič, ekseri i dr. Među navedenima, kako se može videti, javlja se i jedan broj naziva za entitete (npr. crep i cigla) koji se mogu posmatrati na dva načina: ili kao materijali, kada se stojeći u odnosu tipa materijal - predmet sa kućom kao celinom tipološki ne poklapaju, ili pak kao integralni predmeti pojedinih strukturnih delova ove građevine, kada se sa njom kao takođe predmetom tipološki poklapaju (Kuczora \& Cosby 1989: 226). Čini se da je ovakva mogućnost dvostruke perspektive posmatranja, kao i njihova perceptivna istaknutost na kući, omogućila CREPU (16/13) i cIGLI (22/21) dosta dobru kotiranost među svim ostalim delovima kuće na srpskoj listi. Njih po rangu slede i pojedine vrste podnih i/ili zidnih obloga, PARKEt (30/30) i (KERAMIČKE) PLoČICE (32/32), a onda i вцокоvі (41/35). Na američkoj listi, s druge strane, među prvih četrdeset članova kategorije nema nijedne vrste materijala. Niz sa takvim entitetima kreće tek od 49/48.

9 Pojedini od navedenih primera ilustruju i jednu za meronimijske hijerarhije sasvim uobičajenu pojavu da jedan entitet ponekad može predstavljati komponentu više različitih entiteta, odn. da jedna reč može služiti kao meronim čitavom nizu holonima. Zbog takve karakteristike pomenute hijerarhije katkad se nazivaju i zamršenim hijerarhijama (Miller 1990: 257).

10 Odnos između predmeta i materijala od kojih se on pravi, međutim, čest je predmet spora među teoretičarima. Takav odnos Kruz ne smatra vrstom meronimije jer su nazivi za materijale najčešće nebrojive, a nazivi za predmete najčešće brojive imenice, ali i zato što, kako on smatra, delovi neke celine i ta celina moraju biti istog ontološkog tipa, tj. delovi nekog predmeta moraju biti predmeti, delovi nekog vremenskog perioda vremenski periodi, delovi nekog apstraktnog entiteta apstraktni entiteti itd. (Cruse 1995: 177: Cruse \& Croft 2004: 153154). S druge strane, Vinston i dr. ovaj odnos ipak vide kao vrstu meronimije, a on je ujedno i jedan od svega tri odabrana meronimijska odnosa koji se predstavljaju u WordNet-u, velikoj leksičkoj bazi podataka engleskog jezika po čijem uzoru su izrađene ili su trenutno u izradi i leksičke baze većeg broja drugih jezika, uključujući i srpski (Miller 1990: 256; Крстев et al. 2008: 57). 
mesta sa članom siding i nastavlja se sa dosta dalje pozicioniranima: flooring (68/67), TILE$^{1}$ (69/68) i BRICK (74/75). Uzeti kao celina, materijali se, dakle, pretežno vide kao lošiji članovi kategorije.

(6b) Daleko na periferiji kategorije egzistiraju i svi sistemski delovi kuće, tj. razne vrste instalacionih sistema (struja, gas, vodovod, kanalizacija, grejanje i sl.), uključujući ovde i njihove (u perceptivnom smislu uglavnom ne tako istaknute) komponente kao što su cevi, kablovi, žice (mada bi se oni mogli svrstati i među građevinske materijale). Na obe liste kao najbolje kotirani član među njima izdvojio se isti sistemski deo ELEKTRIČNE InSTALACIJE (68/79) / ELECTRICITY (79/82).

(6c) I konačno, izrazitu prednost u odnosu na sve vrste delova kuće i srpski i američki ispitanici daju segmentalnom tipu delova građevine. Segmentalni delovi ne samo da preovlađuju među dobrim predstavnicima posmatrane kategorije već i dominiraju u samom vrhu obe liste predstavljajući njene najtipičnije članove. Među devetnaest prvoplasiranih delova kuće ovom tipu pripada čak šesnaest članova na srpskoj i petnaest na američkoj listi (računajući i GARAGE, koja bi se mogla videti i kao jedna od prostorija u sklopu kuće). Među njima su gotovo podjednako zastupljeni i strukturni, i prostorni delovi. Redosled strukturnih delova (do 19. mesta) na srpskoj i američkoj listi je sledeći: kRov (1/1), PRozori (2/2), VRATA (3/3), teRASA (4/4), STEPENICE (5/5), DiMNJAK/ODŽAK (7/8), Zidovi (8/7), OLUK (17/17); ROOF (5/5), DOORS (7/6), WindoWs (8/7), WALL (9/9), FLOOR $^{1}(=$ pod) $(11 / 11)$, STAIRS $(13 / 14)$ i CELING $(19 / 19)$. Prostorni delovi pak organizuju se po sledećem redosledu: кUPATilo (6/5), KUHinja (9/9), SOBE (10/10), PODRUM (11/11), DNEVNA SOBA / DNEVNI BORAVAK (12/12), ŠPaAZ/OSTAVA (13/16), HODNIK (14/14) i SPAVAĆA SOBA (15/15); BATHROOM (1/1), Kitchen (2/2), BeDRoom (3/3), Living ROOM (4/4), GARAGE (6/8), Dining ROOM (16/12), BASEMENT (17/17) i atтIC (18/18). Pomeranjem granice posmatranja do 28. pozicije, navedenim prvoplasiranim segmentalnim delovima kuće mogu se priključiti još čak pet članova sa srpske liste: PotkRovle (21/23), temel (24/20), tavan (26/24), Plafon/tavanica (27/27) i pod/ PATOs (28/26) i svega dva sa američke liste (na kojoj ovde apsolutno dominiraju elementi pokućstva) i to posmatrano samo prema jednom parametru $\left(\Sigma_{2}\right)$ : SUNROOM / FLORIDA ROOM (31/27) i PORCH / VERANDA (32/28).

Od svih strukturnih delova kuće, dakle, i srpski i američki ispitanici prednost daju istim entitetima - krovu, prozorima i vratima, a od prostornih - kupatilu i kuhinji. Štaviše, sudeći po vrednostima $\Sigma_{1}$ i $\Sigma_{2}$ njihovih naziva koje su daleko veće od sledećih rangiranih članova na listama, navedeni entiteti se ubedljivo izdvajaju kao najtipičniji članovi kategorije. Razlika se, međutim, ogleda u tome što su za većinu srpskih ispitanika najtipičniji delovi kuće u stvari pomenuti strukturni, a za američke pomenuti prostorni delovi. Ipak, dodeljena visoka pozicioniranost istim strukturnim delovima od strane oba uzorka ispitanika implicitno ukazuje na ono što se, gledano iz pozicije ukućana, od jedne kuće najviše i očekuje: pre svega, da pruži zaštitu od nepovoljnih spoljnih uticaja koji, kako se izgleda doživljava, najpre dolaze s neba (krov), da u svojoj unutrašnjosti ima neophodnu prirodnu svetlost (prozori) i da ima vezu sa spoljašnjošću, odn. da ukućanima obezbedi mogućnost kretanja u pravcu spolja-unutra i obrnuto (vrata). Imajući sada u vidu i funkcije izdvojenih prostornih delova u kući, izgleda da su od svih osnovnih potreba koje ukućani mogu da zadovolje unutar kuće za anketirane ispitanike ipak najvažniji higijena (kupatilo) i ishrana (kuhinja). 


\section{ZAKLJUČNA REČ}

U ovom radu iznet je pregled sličnosti i razlika između dva uzorka ispitanika, govornika srpskog i govornika engleskog jezika, u poimanju kuće kao celine, klasifikovanju entiteta u kategoriju njenih delova i njihovoj organizaciji unutar kategorije. Rezultati poređenja pokazuju da obe grupe ispitanika kuću kao celinu vide i kao građevinsku strukturu, i kao sadržatelja, i kao šire prodručje/prostor koji osim građevinske strukture zahvata i okućnicu. Stoga su u kategoriju delovi kuć svrstani najrazličitiji entiteti koji su u radu grupisani u nekoliko grupa: entiteti koji se uvek nalaze izvan kuće kao glavne zgrade na imanju (delovi okućnice), entiteti koji se alternativno mogu naći ili unutar ili izvan nje, entiteti koji se nalaze u kući ali nisu deo same građevinske strukture (pokućstvo) i entiteti koji predstavljaju delove same građevinske strukture razvrstani na segmentalne delove (strukturne i prostorne), sistemske delove i građevinske materijale.

Ipak, sudeći ne samo po manjem broju navedenih naziva za delove okućnice već i po njihovoj, generalno uzevši, lošijoj pozicioniranosti unutar kategorije, 'kuća kao celina', vrlo retko se tumači tako da zahvata i područje/prostor neposredno oko kuće. Naziv kategorije kao zadati stimulus ispitanike je ipak prevashodno asocirao na građevinski objekat (znatno češće srpske) i njegov sadržaj (znatno češće američke ispitanike). Od svih delova same građevinske strukture najlošije su pozicionirani svi sistemski delovi kuće, koje čak pretiču i pojedine vrste (u literaturi na temu meronimije najčešće spornih) materijala, uglavnom one koje se mogu posmatrati ne samo kao mase nego i kao pojedinačni predmeti (npr. crep i cigla). Segmentalne delove kuće oba uzorka ispitanika smatraju najboljim predstavnicima kategorije, s tim što srpski ispitanici u tom pogledu prednost daju strukturnim, a američki prostornim delovima. Usredsređenost američkih ispitanika na unutrašnji prostor kuće ogleda se ne samo u znatno većem broju navedenih naziva za prostorije sa različitim namenama, već i u podosta boljoj pozicioniranosti istih elemenata pokućstva unutar kategorije. Štaviše, nekolicina njih, pretežno iz kategorije nameštaja, na američkoj listi je našla svoje mesto čak i na područjima vrlo bliskim samom jezgru kategorije. Prema srpskim ispitanicima pak na takvim područjima su i dalje dominantni segmentalni delovi građevine.

\section{LITERATURA}

Croft, W. \& D. A. Cruse. 2004. Cognitive Linguistics. Cambridge: CUP.

Cruse, D. A. 1995. Lexical Semantics. Second Edition. Cambridge: CUP.

Дилпарић, Б. 2011. Унутрашња структура категорије ДЕЛОВИ кУЋЕ. Филолог: часопис за језик, књижевност и културу 4. Бања Лука: Универзитет у Бањој Луци, Филолошки факултет, 132-146.

Dilparić, B. 2012. Semantic Organization of the HOUSE PARTS Category as Perceived by American Subjects. Превод у систему компаративних изучавања националне и стране књижевности и културе (Међународни тематски зборникрадова). Косовска Митровица: Филозофски факултет Универзитета у Приштини, 279-307. 
Gerstl, P. \& S. Pribbenow. 1995. Midwinters, End Games, and Body Parts: A Classification of Part-Whole Relations. International Journal of Human-Computer Studies 43/5-6, 865-889.

Крстев, Ц., Б. Ђорђевић, С. Антонић, Н. Ивковић-Берчек, З. Зорица, В. Црногорац, Љ. Мацура. 2008. Кооперативни рад на доградњи српског wordneta. ИНФ0тека: часопис за библиотекарство и информатику 1-2. Београд: Заједница библиотека универзитета у Србији, 57-75.

Kuczora, P. W. \& S. J. Cosby. 1989. Implementation of Meronymic (Part-Whole) Inheritance for Semantic Networks. Knowledge-Based Systems 2/4. Butterworth \& Co (Publishers) Ltd, 219-227.

Lakoff, G. \& M. Johnson. 2003. Metaphors We Live By. Chicago and London: The University of Chicago Press.

Mervis, C. B., J. Catlin \& E. Rosch. 1976. Relationships Among Goodness-of-Example, Category Norms, and Word Frequency. Bulletin of the Psychonomic Society $7 / 3$, 283-297.

Miller, G. A. 1990. Nouns in WordNet: A Lexical Inheritance System. International Journal of Lexicography, 3/4. 0xford: OUP, 245-264.

Murphy, M. L. 2003. Semantic Relations and the Lexicon: Antonymy, Synonymy and Other Paradigms. Cambridge: CUP.

Murphy, M. L. 2006. Meronymy. In K. Brown (ed.) Encyclopedia of Language and Linguistics, Second Edition, Vol. 8. 0xford: Elsevier Ltd., 13-15.

Radden, G. \& R. Dirven. 2007. Cognitive English Grammar. Amsterdam and Philadelphia: John Benjamins Publishing Company.

Rosch, E. 1975. Cognitive Representations of Semantic Categories.Journal of Experimental Psychology: General 104/3, 192-233.

Šipka, D. 1998. Osnovi leksikologije i srodnih disciplina. Novi Sad: Matica srpska, Odeljenje za književnost i jezik.

Winston, M. E., R. Chaffin \& D. Herrmann. 1987. A Taxonomy of the Part-Whole Relations. Cognitive Science 11, 417-444.

\section{SUMMARY}

\section{SEMANTIC ORGANIZATION OF HOUSE PARTS AS PERCEIVED BY SERBIAN AND AMERICAN SUBJECTS}

This paper compares the survey data obtained from native speakers of Serbian in Kosovska Mitrovica, Serbia, and native speakers of (American) English in Atlanta, Georgia, USA. The objective of the survey was twofold: (1) to provide insights into the internal structure of the HOUSE PARTS category, and (2) to determine what types of entities are generally classified into this category. The internal category structure was measured by the frequency and order with which the category members were named by the subjects in response to the category name. The study shows that the category is generally considered to include not only parts of the building itself, but also a large variety of household items it may contain, as well as surface/spatial entities found on a 
property area outside it. However, segmental parts of the building, seen either in terms of spaces or in terms of the structural elements that define those spaces, are regarded by both Serbian and American subjects as the best examples of the category.

KEYWORDS: prototype theory, category, internal structure, part-whole relations (meronymy), HOUSE PARTS.

(Originalan naučni rad primljen 18.03.2012; ispravljen 14.12.2012; prihvaćen 17.12.2012) 